Jurnal Keperawatan Padjadjaran

ISSN 2338-5324 (print)

ISSN 2442-7276 (online)

Online di http://jkp.fkep.unpad.ac.id

DOI : $10.24198 / \mathrm{jkp}$

\title{
Symptom Burden's Associated Factors among Hemodialysis Patients
}

\author{
Early Octavia Limbong, Tuti Pahria*, Sri Hartati Pratiwi \\ Faculty of Nursing, Universitas Padjadjaran, Bandung, Indonesia \\ Corresponding Email: tuti.pahria@unpad.ac.id
}

Submitted: 19-08-2020 Accepted: 05-11-2020 Published: 01-12-2020

\begin{abstract}
Many patients with chronic kidney disease undergoing hemodialysis (CKD-HD) had a high symptom burden, which can worsen their health conditions and quality of life. The known factors associated to symptom burden were age, gender, hemodialysis (HD) session duration, post dialysis recovery time, hemoglobin level, nutrition status, physical activity, depression level and social support. The aim of this study was to analyze the most dominant factor associated to symptom burden among CKD-HD patients. Using a cross-sectional design, a convenience sample of eighty-five respondents were recruited from HD unit at Adventist Bandung Hospital, who underwent HD $>3$ months, HD frequency 2-3 times a week, aged $\geq 18$ years, able to communicate and speak Indonesian. Data were retrieved via seven self-reported questionnaires and health records, and the symptom burden was assessed using the validated Indonesian version of the CKD-Symptom Burden Index. The data was analysed with Spearman correlation test, Chi square test, and multivariate logistic regression. Based on quartile category, most of the respondents $(50.6 \%)$ had a high symptom burden $(33.56 \pm 12.23)$. The factors significantly associated to symptom burden were age $(\mathrm{p}=0.015)$, post-dialysis recovery time $(\mathrm{p}=0.007)$ and depression level $(\mathrm{p}=0.000)$. In the final model, duration of HD session $(\mathrm{OR}=5.27,95 \%$ CI 1.50-18.49) and depression level $(\mathrm{OR}=8.84,95 \%$ CI 2.57-30.36) were the factors associated to high symptom burden. Depression level was the most dominant factor associated to high symptom burden. CKDHD patients with depression are more at risk of experiencing a high symptom burden. Thus, symptom management may consider to modify depression level factor by screening for depression, providing assistance and nursing interventions, or developing depression-related interventions to reduce symptom burden in CKD-HD patients.
\end{abstract}

Keywords: Hemodialysis, physiology, psychology, situational, symptom burden. 
Early Octavia Limbong: Symptom Burdens Associated Factors among Hemodialysis Patients

\section{Introduction}

Patient with chronic kidney disease (CKD) who underwent hemodialysis was also known as CKD-HD (PERNEFRI, 2011). CKD-HD was one of the groups with a high symptom burden compared to a group of patients with peritoneal dialysis and CKD 4 \& 5 non dialysis (Almutary, Bonner, \& Douglas, 2016). In 2018, CKD 5 prevalence in the US were 124,456 patients and $87.5 \%$ had hemodialysis (HD) (USRDS, 2018). In Indonesia, in 2018, there were 132,142 CKD 5 patients and $98 \%$ had HD actively (IRR, 2018). Even though HD can replace some of the normal kidney physiologic functions and prolong the life expectancy, but HD could not cure the comorbidity and the patient's uremic symptoms was still high (Almutary, Bonner, \& Douglas, 2013).

Symptom burden was defined as a combination of several subjective symptoms, physically and psychologically from frequency dimension, severity, duration and symptom distress experienced by the patients (Desbiens, 1999). Patient with CKD-HD might have many physical and psychological symptoms at once from several sources because CKD itself had a multi systemic effect which the symptoms could appear simultaneously and interrelated, it turned to become symptom burden and affected to the patient's health (Li, Xie, Yang, \& Pang, 2018).

High symptom burden in CKD-HD patient had an adverse impact to a patient's life quality (Song et al., 2018; Danquah et al., 2010; Delmas et al., 2017; Lowney et al., 2015) and decrease physical performance (Kopple et al., 2015), physical activity level (Clarke et al., 2015), and life well-being (Song et al., 2018). Further, Sexton et al. (2016) research stated that one of the factor found associated to mortality risk was a higher symptom burden.

Based on its characteristic, symptom burden was conceptualized as multidimensions, which was prevalence, distress or disturbance, severity, and symptoms frequency (Gapstur, 2007). The previous study revealed that CKD-HD patient's symptom burden score was $23.36 \pm 16.99$ (Almutary et al., 2016); and 29.6 \pm 16.8 (Karasneh et al., 2020) using
Chronic Kidney Disease-Symptom Burden Index (CKD-SBI). Commonly the CKD-HD patients had $15.32 \pm 7.65$ symptoms, twice higher than any other groups (PD, CKD 4\&5 non dialysis), four most common symptoms were fatigue, join pain, pruritus or itch, and lack of appetite (Almutary et al., 2016). The most disturbing symptoms were tiredness, difficulty to fall asleep, headache, difficulty to stay asleep, dry skin, numb/tingling, join pain and pruritus or itch (Danquah et al., 2010). The most severe symptoms were sleep disorder, skin disorder, bone or join pain, coughing, muscle pain and sexual problem (Almutary et al., 2016). According to Davison and Jhangri (2010), the symptoms severity level was on moderate to severe category. The most frequent symptoms experienced were sleep disorder, skin disorder, bone or join pain, restless leg, dizziness and cough (Almutary et al., 2016).

One of the nursing concept focused on symptom management was unpleasant symptoms theory (TOUS). TOUS was based on three major components which were symptoms, symptoms associated factors (physiology, psychology, situational) and a client performance (Lenz et al., 1997). Therefore, this research had made TOUS as a guidance to identify the symptom burden associated factors. In the previous research, the identified variables associated to symptom burden were age (Almutary, Bonner, \& Douglas, 2016; Caplin, Kumar, \& Davenport, 2011; Danquah et al., 2010; Song et al. 2018), gender (Almutary et al., 2016; Caplin, Kumar, \& Davenport, 2011; Danquah et al., 2010; Karasneh et al. 2020), race (Caplin, Kumar, \& Davenport, 2011), HD modality itself (Almutary et al., 2016; Cervantes et al., 2018), HD session duration (Caplin, Kumar, \& Davenport, 2011), post dialysis recovery time (Caplin, Kumar, \& Davenport, 2011; Lopes et al., 2014; Rayner et al., 2014), hemoglobin (Hb) level (Yu, Huang, \& Tsai, 2012), nutritional status (Randall et al., 2019), physical activity ( $\mathrm{Ng}$ et al., 2020; Song et al., 2018), depression level (Song et al., 2018; Son et al., 2009; Wan Zukiman et al., 2017), hemodialysis process at the HD centre (Caplin, Kumar, \& Davenport, 2011), and social support (Dano et al., 2018; Gao et al., 2016). But, there were some inconsistent 
results among those factors and there was not any previous research whom evaluate the most affected factor to symptom burden in CKD-HD patients population.

This research was made to analyse the most dominant factor associated to symptom burden among variable factors (age, gender, duration of $\mathrm{HD}$ session, recovery time, $\mathrm{Hb}$ level, nutritional status, physical activity, depression level and social support). Thus, the symptom management could consider to modify the most associated factor to symptom burden and was expected to reduce the CKDHD patient's symptom burden.

\section{Method}

This study was a cross sectional design and convenience sampling technique was used to collected the samples with inclusive CKDHD patient criteria who had $>3$ months HD, with 2-3 times HD frequency a week, patient was $\geq 18$ years old, able to communicate and to speak in Indonesian. The sample size of this study used rule of thumb formula (Roscoe 1982 in Sugiyono, 2018), the number of sample recommended should be at least 10 times the number of research variables, it was apparently 100 respondents. From the 118 accessible populations only eighty-five CKD-HD patients were involved in this study. Since, thirty patients were involved in pilot study of Indonesian version of CKD-Symptom Burden Index (CKD-SBI) and recovery time post dialysis that should had been carried out in another HD unit, but the related parties did not provide permission due to pandemic of Coronavirus Disease (COVID-19), and three patients died during the study.

There were seven questionnaires in this study: 1) Instruments for collecting demographic data, consisting of age, gender, HD sessions duration, Hb levels; 2) Nutritional status measured by the Dialysis Malnutrition Score (DMS) (Kalantar-Zadeh et al., 1999). DMS was available in Indonesian in Nur's (2017) study with the validity test that the sensitivity and specificity are good, $81.3 \%$ and $71.4 \%$; 3) Depression level measured by the Patient Health Questionnaire (PHQ9) (Kroenke et al., 2001). PHQ-9 has been translated into Indonesian in Linden's (2019) study with the reliability test results of the intraclass coefficient is 0.713 and at the construct validity there was a correlation between PHQ-9 and the Beck Depression Index; 4) Physical activity measured by the Rapid Assessment of Physical Activity (RAPA-1) (Topolski et al., 2006), which was translated in Indonesian and published in the guidebook Program at Workplace by the Kementrian Kesehatan RI (2016); 5) Social support was measured by the Medical Outcomes Study: Social Support Survey (MOS-SSS) (Sherbourne \& Stewart, 1991). MOS-SSS was translated in Indonesian in the study of Abrori and Ahmad (2018), the validity and reliability test stated that each MOS-SSS domain had a positive and significant correlation $(0.72-0.89) ; 6)$ Recovery time post dialysis (Lindsay et al., 1999) was not available in Indonesian, it was adapted into Indonesian and was permitted by the developer of the questionnaire. Questionnaire translation was done by Brislin (1970) method, through direct translation, back-translation, decentering by asking the item content relevancy evaluation from three experts. The item-content validitiy index (i-CVI) score was 0.67 , this showed that item validity content was not good enough. Then, the recovery time question was revised to "How long does it take you to recover (back to normal condition, return to activity) after hemodialysis session?"; 7) Symptom burden was measured by the CKD-Symptom Burden Index (CKD-SBI) (Almutary et al., 2015), assessing 32 multidimensional CKD-related symptoms (prevalence, distress, severity, frequency). The total symptom burden is the sum of the scores for each dimension and then multiplying the result by 0.1008 (constant number), the CKD-SBI total score ranges from 0-100. This questionnaire was also adapted into Indonesian and was permitted by the developer of the questionnaire. The translation was carried out using the Brislin (1970) method, the i-CVI CKD-SBI value was $0.98(\geq 0.80)$, which means good (Polit \& Beck, 2004). Next, CKD-SBI questionnaire reliability was tested on 30 respondents, using Cronbach's Alpha with reliability coefficient score in all burden dimensions was above 0.80 , which means reliable. Symptom burden 
Early Octavia Limbong: Symptom Burdens Associated Factors among Hemodialysis Patients

was categorized based on symptom burden quartile score into three categories (Karasneh et al., 2020) low, moderate and high.

The data was analysed through univariate, bivariate with Spearman correlation test and contingency coefficient with Chi square test. Significant level was $\alpha<0,05$. Multivariate analysis was using logistic regression with enter method, during the analysis, the symptom burden categories were split into the new dichotomous variables.
Ethical approval was obtained from the research ethics committee of Padjadjaran University, Bandung (reference number: 473/UN6.KEP/EC/2020. Date 12/05/2020). Written informed consent was obtained from the respondents before data collection and data was collected for a month (May-June 2020).

\section{Results}

Table 1 Respondent Characteristics, Independent Variables and Symptom Burden on CKD-HD Patients in HD Unit at Adventist Hospital Bandung

\begin{tabular}{|c|c|c|c|c|c|c|}
\hline Variable & $\begin{array}{c}\text { Total Sample } \\
\text { N (\%) }\end{array}$ & $\begin{array}{c}\text { Low } \\
\text { N (\%) }\end{array}$ & $\begin{array}{c}\text { Moderate } \\
\text { N }(\%)\end{array}$ & $\begin{array}{l}\text { High } \\
\text { N }(\%)\end{array}$ & $\mathbf{r}$ & p-value \\
\hline \multicolumn{7}{|l|}{ Age (year) } \\
\hline Mean SD & $50.68 \pm 13.53$ & $52.86 \pm 13.13$ & $55.76 \pm 13.69$ & $47.14 \pm 12.91$ & -0.262 & $0.015^{*}$ \\
\hline \multicolumn{7}{|l|}{ Gender } \\
\hline Male & $48(56.5 \%)$ & $14(29.2 \%)$ & $10(20.8 \%)$ & $24(50.0 \%)$ & 0.057 & 0.457 \\
\hline Female & $37(43.5 \%)$ & $7(18.9 \%)$ & $11(29.7 \%)$ & $19(51.4 \%)$ & & \\
\hline \multicolumn{7}{|l|}{$\begin{array}{l}\text { Duration of HD } \\
\text { Session }\end{array}$} \\
\hline 3-4 hours & $45(52.9 \%)$ & $15(33.3 \%)$ & $10(22.2 \%)$ & $20(44.4 \%)$ & 0.178 & 0.103 \\
\hline$>4$ hours & $40(47.1 \%)$ & $6(15.0 \%)$ & $11(27.5 \%)$ & $23(57.5 \%)$ & & \\
\hline \multicolumn{7}{|l|}{$\begin{array}{l}\text { Recovery Time } \\
\text { (minute) }\end{array}$} \\
\hline Mean \pm SD & $\begin{array}{c}532.06 \pm \\
642.01\end{array}$ & $468.33 \pm 738.68$ & $236.43 \pm 431.54$ & $707.56 \pm 631.32$ & 0.293 & $0.007 *$ \\
\hline \multicolumn{7}{|l|}{$\begin{array}{l}\text { Hemoglobin (g/ } \\
\text { dL) }\end{array}$} \\
\hline Mean \pm SD & $9.59 \pm 2.07$ & $9.55 \pm 1.81$ & $9.37 \pm 2.07$ & $9.71 \pm 2.21$ & -0.056 & 0.611 \\
\hline \multicolumn{7}{|l|}{ Nutritional Status } \\
\hline Normal & $74(87.1 \%)$ & $20(27.0 \%)$ & $20(27.0 \%)$ & $34(45.9 \%)$ & 0.227 & 0.130 \\
\hline Mild Malnutrition & $11(12.9 \%)$ & $1(9.1 \%)$ & $1(9.1 \%)$ & $9(81.8 \%)$ & & \\
\hline \multicolumn{7}{|l|}{ Physical Activity } \\
\hline Sedentary & $9(10.6 \%)$ & $1(11.1 \%)$ & $3(33.3 \%)$ & $5(55.6 \%)$ & -0.120 & 0.273 \\
\hline Under-active & $11(12.9 \%)$ & $3(27.3 \%)$ & $3(27.3 \%)$ & $5(45.5 \%)$ & & \\
\hline Mild & $12(14.1 \%)$ & $4(33.3 \%)$ & $1(8.3 \%)$ & $7(58.3 \%)$ & & \\
\hline Moderate & $19(22.4 \%)$ & $3(27.3 \%)$ & $3(15.8 \%)$ & $13(38.2 \%)$ & & \\
\hline Very active & $34(40.0 \%)$ & $1(29.4 \%)$ & $11(32.4 \%)$ & $13(38.2 \%)$ & & \\
\hline \multicolumn{7}{|l|}{ Depression Level } \\
\hline None Depression & $35(41.2 \%)$ & $15(42.9 \%)$ & $13(37.1 \%)$ & $7(20.0 \%)$ & 0.546 & $0.000^{*}$ \\
\hline Mild Depression & $26(30.6 \%)$ & $4(15.4 \%)$ & $7(26.9 \%)$ & $15(57.7 \%)$ & & \\
\hline $\begin{array}{l}\text { Moderate } \\
\text { Depression }\end{array}$ & $16(18.8 \%)$ & $2(12.5 \%)$ & $1(6.3 \%)$ & $13(81.3 \%)$ & & \\
\hline
\end{tabular}


Early Octavia Limbong: Symptom Burdens Associated Factors among Hemodialysis Patients

\begin{tabular}{|c|c|c|c|c|c|c|}
\hline $\begin{array}{l}\text { Moderately Severe } \\
\text { Depression }\end{array}$ & $8(9.4 \%)$ & $0(0.0 \%)$ & $0(0.0 \%)$ & $8(100.0 \%)$ & & \\
\hline \multicolumn{7}{|l|}{ Social Support } \\
\hline Less & $17(20 \%)$ & $2(22.8 \%)$ & $4(23.5 \%)$ & $11(64.7 \%)$ & -0.161 & 0.141 \\
\hline Good & $68(80 \%)$ & $19(27.9 \%)$ & $17(25.0 \%)$ & $32(47.1 \%)$ & & \\
\hline \multicolumn{7}{|l|}{ Comorbidity } \\
\hline Hypertension & $51(60.00 \%)$ & & & & & \\
\hline Diabetes Mellitus & $10(11.76 \%)$ & & & & & \\
\hline $\begin{array}{l}\text { Cardiovascular } \\
\text { disease }\end{array}$ & $5(5.88 \%)$ & & & & & \\
\hline Tuberculosis & $1(1.18 \%)$ & & & & & \\
\hline Malignancy & $0(0.00 \%)$ & & & & & \\
\hline $\begin{array}{l}\text { Cerebrovascular } \\
\text { disease }\end{array}$ & $1(1.18 \%)$ & & & & & \\
\hline $\begin{array}{l}\text { Urinary tract } \\
\text { disease }\end{array}$ & $0(0.00 \%)$ & & & & & \\
\hline Digestive disease & $0(0.00 \%)$ & & & & & \\
\hline Hepatitis C & $3(3.53 \%)$ & & & & & \\
\hline Others & $5(5.88 \%)$ & & & & & \\
\hline $\begin{array}{l}\text { Without } \\
\text { comorbidity }\end{array}$ & $9(10.58 \%)$ & & & & & \\
\hline \multicolumn{7}{|l|}{ Symptom Burden } \\
\hline Low & $21(24.7 \%)$ & & & & & \\
\hline Moderate & $21(24.7 \%)$ & & & & & \\
\hline High & $43(50.6 \%)$ & & & & & \\
\hline
\end{tabular}

$\mathrm{a}=$ Spearman Correlation test; $b=$ Chi-Square test, ${ }^{*}$ ) Significant value $\mathrm{p}<0.05$

Tabel 2 Symptom Burden Dimension on CKD-HD Patients in HD Unit at Adventist Hospital Bandung

\begin{tabular}{lcccc}
\hline \multicolumn{1}{c}{ Symptoms } & $\begin{array}{c}\text { Prevalence } \\
\text { n (\%) }\end{array}$ & $\begin{array}{c}\text { Distress } \\
\text { Mean } \pm \text { SD }\end{array}$ & $\begin{array}{c}\text { Severity } \\
\text { Mean } \pm \text { SD }\end{array}$ & $\begin{array}{c}\text { Frequency } \\
\text { Mean } \pm \text { SD }\end{array}$ \\
\hline Constipation & $23(27.1)$ & $1.14 \pm 2.31$ & $0.95 \pm 2.02$ & $1.11 \pm 2.36$ \\
Nausea & $44(51.8)$ & $2.07 \pm 2.75$ & $1.81 \pm 2.50$ & $1.79 \pm 2.30$ \\
Vomit & $28(32.9)$ & $1.34 \pm 2.37$ & $1.22 \pm 2.26$ & $1.02 \pm 2.04$ \\
Diarrhea & $19(22.4)$ & $1.05 \pm 2.55$ & $0.93 \pm 2.40$ & $0.95 \pm 2.26$ \\
Decreased appetite & $38(44.7)$ & $1.96 \pm 3.13$ & $1.93 \pm 2.85$ & $1.93 \pm 2.77$ \\
Muscle cramp & $50(58.8)$ & $2.73 \pm 3.01$ & $2.53 \pm 2.92$ & $2.25 \pm 2.63$ \\
Swollen leg & $30(35.3)$ & $1.53 \pm 2.52$ & $1.46 \pm 2.43$ & $1.49 \pm 2.36$ \\
Breathing difficulty & $37(43.5)$ & $1.85 \pm 2.73$ & $1.92 \pm 2.63$ & $1.71 \pm 2.33$ \\
Mild headache or & $49(57.6)$ & $2.56 \pm 3.13$ & $2.45 \pm 2.95$ & $2.48 \pm 2.89$ \\
dizziness & & & & $0.63 \pm 1.74$ \\
Restless leg & $20(23.5)$ & $0.73 \pm 1.92$ & $0.64 \pm 1.77$ & $1.18 \pm 2.32$ \\
$\begin{array}{l}\text { Numbness or feet } \\
\text { tingling }\end{array}$ & $25(29.4)$ & $1.16 \pm 2.28$ & $1.25 \pm 2.38$ & \\
\hline
\end{tabular}


Early Octavia Limbong: Symptom Burdens Associated Factors among Hemodialysis Patients

\begin{tabular}{|c|c|c|c|c|}
\hline $\begin{array}{l}\text { Fatigue or lack of } \\
\text { energy }\end{array}$ & $68(80.0)$ & $3.56 \pm 2.97$ & $3.40 \pm 2.91$ & $3.64 \pm 2.88$ \\
\hline Coughing & $35(41.2)$ & $1.72 \pm 2.66$ & $1.62 \pm 2.64$ & $1.49 \pm 2.40$ \\
\hline Dry mouth & $37(43.5)$ & $1.52 \pm 2.46$ & $1.48 \pm 2.41$ & $1.69 \pm 2.71$ \\
\hline Bone or joint pain & $49(57.6)$ & $2.85 \pm 3.32$ & $2.68 \pm 3.16$ & $2.60 \pm 3.15$ \\
\hline Chest pain & $26(30.6)$ & $1.34 \pm 2.35$ & $1.27 \pm 2.38$ & $1.16 \pm 2.12$ \\
\hline Headache & $41(48.2)$ & $2.36 \pm 3.27$ & $2.19 \pm 2.97$ & $2.13 \pm 2.98$ \\
\hline Muscle pain & $51(60.0)$ & $2.32 \pm 2.81$ & $2.38 \pm 2.84$ & $2.49 \pm 2.84$ \\
\hline $\begin{array}{l}\text { Concentration } \\
\text { difficulty }\end{array}$ & $38(44.7)$ & $1.75 \pm 2.55$ & $1.69 \pm 2.49$ & $1.82 \pm 2.59$ \\
\hline Dry skin & $62(72.9)$ & $3.25 \pm 3.07$ & $3.19 \pm 2.94$ & $3.40 \pm 3.13$ \\
\hline Itch/pruritus & $48(56.5)$ & $2.53 \pm 3.13$ & $2.33 \pm 2.96$ & $2.42 \pm 2.96$ \\
\hline Anxiety & $43(50.6)$ & $2.18 \pm 2.88$ & $2.13 \pm 2.80$ & $2.29 \pm 2.93$ \\
\hline Nervous & $29(34.1)$ & $1.49 \pm 2.51$ & $1.34 \pm 2.39$ & $1.53 \pm 2.59$ \\
\hline $\begin{array}{l}\text { Difficulty to fall } \\
\text { asleep }\end{array}$ & $62(72.9)$ & $4.09 \pm 3.63$ & $4.05 \pm 3.46$ & $4.08 \pm 3.52$ \\
\hline $\begin{array}{l}\text { Difficulty to stay } \\
\text { asleep }\end{array}$ & $58(68.2)$ & $4.00 \pm 3.59$ & $3.96 \pm 3.52$ & $4.25 \pm 3.60$ \\
\hline Annoyed & $48(56.5)$ & $2.53 \pm 2.96$ & $2.44 \pm 2.87$ & $2.53 \pm 2.90$ \\
\hline $\mathrm{Sad}$ & $41(48.2)$ & $1.98 \pm 2.76$ & $1.95 \pm 2.65$ & $1.95 \pm 2.64$ \\
\hline Worried & $41(48.2)$ & $1.88 \pm 2.74$ & $1.88 \pm 2.68$ & $1.89 \pm 2.68$ \\
\hline Depression & $16(18.8)$ & $0.73 \pm 1.98$ & $0.73 \pm 1.98$ & $0.78 \pm 2.01$ \\
\hline $\begin{array}{l}\text { Interest decreased } \\
\text { in sexual intercourse }\end{array}$ & $43(50.6)$ & $2.76 \pm 3.56$ & $3.06 \pm 3.69$ & $3.05 \pm 3.74$ \\
\hline $\begin{array}{l}\text { Difficulty to arouse } \\
\text { sexually }\end{array}$ & $37(43.5)$ & $2.45 \pm 3.43$ & $2.71 \pm 3.62$ & $2.73 \pm 3.67$ \\
\hline Nocturia & $17(20.0)$ & $0.68 \pm 1.88$ & $0.68 \pm 1.88$ & $0.75 \pm 1.93$ \\
\hline $\begin{array}{l}\text { Score subscale } \\
(\text { Mean } \pm \text { SD) }\end{array}$ & $14.80 \pm 7.63$ & $66.11 \pm 51.53$ & $64.25 \pm 50.07$ & $65.22 \pm 48.63$ \\
\hline
\end{tabular}

Characteristics of Respondents and Independent Variable Correlation

Table 1 indicated that mean age of the respondents was $50.68 \pm 13.53$ years, the majority were male $(56.5 \%)$, had hypertension as a comorbid $(60.00 \%)$, with a 3-4 hours of HD duration session (52.9\%). The postdialysis recovery time mean was $532.06 \pm$ 642.01 minutes and the $\mathrm{Hb}$ level mean was $9.59 \pm 2.07 \mathrm{~g} / \mathrm{dL}$. In general, respondents had normal nutritional status $(87.1 \%)$, had a mild to moderately severe level of depression $(58.8 \%)$ and had good social support (80\%). Based on the symptom burden quartile score, the majority of respondents experienced a high symptom burden $(50.6 \%)$. The bivariate analysis result showed that there were three variables that had a significant relationship with symptom burden ( $p<0.05)$, which were age, post-dialysis recovery time and depression level.

\section{Symptom Burden}

Table 2 showed that the respondent experienced $14.80 \pm 7.63$ symptoms, the five most common were fatigue, difficulty to fall asleep, dry skin, difficulty to stay asleep, and muscle pain. The five most disturbing symptoms were difficulty to fall asleep, difficulty to stay asleep, fatigue, dry skin, bone or joint pain $(66.11 \pm 51.53)$. The five most severe symptoms were difficulty to fall asleep, difficulty to stay asleep, fatigue, dry skin, decreased interest in sex $(64.25$ \pm 50.07). The five symptoms frequently reported were difficulty to stay asleep, difficulty to fall asleep, fatigue, dry skin, decreased interest in sex $(65.22 \pm 48.63)$. 
The total symptom burden score was 21.21 \pm 15.68 (data not attached) and based on the quartile of symptom burden score (table 1), the majority of respondents experienced high symptom burden (50.6\%).

\section{Most Dominant Factor Related to Symptom Burden}

The independent variables which had a $\mathrm{p}$ value $<0.25$ on the bivariate (six variables) were included in the logistic regression analysis. In the final modeling, there were two variables that had a significant value, the duration of the HD session $(p=0.009)$ and depression level $(p=0.001)$. In the next step, an interaction between the two variables was carried out with the result of $p=0.738$ ( $p>$ 0.05 ) (table 3 ), which meant that there was no interaction between the duration of the HD session and the level of depression. The valid model was a model without any interaction; thus, the duration of HD session and the level of depression were entered into the final model (table 4).

The most dominant factor variable related to symptom burden based on the Odds Ratio (OR) value was depression level (8.84). CKD-HD patients with depression had an 8.84 times greater risk of experiencing a high symptom burden compared to CKD-HD patients who were not depressed after an HD sessions duration was controlled. Meanwhile, CKD-HD patients with $>4$ hours HD duration had a 5.27 times greater risk to experience a high symptom burden, compared to CKDHD patients with 3-4 hours HD duration session which the depression level variable was already control.

Table 3 Interaction Test Result

\begin{tabular}{lcccccc}
\hline \multicolumn{1}{c}{ Variable } & $\boldsymbol{\beta}$ & S.E & Wald & $\begin{array}{c}\text { OR } \\
(\mathbf{E x p} \boldsymbol{\beta})\end{array}$ & $\mathbf{9 5 \%}$ CI & p-value \\
\hline $\begin{array}{l}\text { Duration of } \\
\text { HD Session }\end{array}$ & 1.663 & 0.640 & 6.753 & 5.275 & $1.51-18.49$ & 0.009 \\
$\begin{array}{l}\text { Depression } \\
\text { Level }\end{array}$ & 2.180 & 0.629 & 12.002 & 8.846 & $2.57-30.36$ & 0.001 \\
$\begin{array}{l}\text { Duration } \\
\text { of HD }\end{array}$ & - & - & - & - & - & 0.738 \\
$\begin{array}{l}\text { Session by } \\
\text { Depression }\end{array}$ & & & & & & \\
$\begin{array}{l}\text { Level } \\
\text { Constanta }\end{array}$ & -0.625 & 0.503 & 1.542 & 0.535 & & \\
\hline
\end{tabular}

Table 4 Result of Logistic Regression Test

\begin{tabular}{lcccccc}
\hline \multicolumn{1}{c}{ Variable } & $\boldsymbol{\beta}$ & S.E & Wald & $\begin{array}{c}\text { OR } \\
(\mathbf{E x p} \boldsymbol{\beta})\end{array}$ & $\mathbf{9 5 \%} \mathbf{C I}$ & p-value \\
\hline $\begin{array}{l}\text { Duration of } \\
\text { HD Session }\end{array}$ & 1.663 & 0.640 & 6.753 & 5.275 & $1.51-18.49$ & 0.009 \\
$\begin{array}{l}\text { Depression } \\
\text { Level }\end{array}$ & 2.180 & 0.629 & 12.002 & 8.846 & $2.57-30.36$ & 0.001 \\
Constanta & -0.625 & 0.503 & 1.542 & 0.535 & & \\
\hline
\end{tabular}

\section{Discussion}

The result of this study indicated that the majority of respondents $(50.6 \%)$ were classified to have a high symptom burden $(33.56 \pm 12.23)$, with symptom burden score was $21.21 \pm 15.68$ (data not attached). This result was found lower than the previous studies (Almutary et al., 2016; Karasneh et al., 2020). Differences in symptom burden results with previous studies might be affected by varies type of symptom burden instrument used, cultural differences which affected the perception of symptoms, varies of dialysis technique practice, psychological condition, uremic condition, or less adequate dialysis (Almutary et al., 2016; Brennan, Siva, \& Crail, 2013). 
There was an association between younger age and symptom burden, in line with the result of studies by Caplin et al. (2011) and Song et al. (2018. However, this result was not corresponded to Almutary et al. (2016) study, which declared that the older age was related to symptom burden. Older patient may report a lower symptom burden because they had already at the stage of self-acceptance and its complications, and had learnt to live with those symptoms (Danquah et al., 2010; Orenstein \& Lewis, 2020) and had a lower expectation in terms of quality of life (Caplin et al., 2011).

There was not any association between the HD session duration and symptom burden in bivariate analysis. This was in line with the result of study by Karasneh et al. (2020). However, based on the results of the multivariate analysis, the HD session duration was one of the factors associated with a high symptom burden $(p=0.009)$. The possible reason why the association was finally found was because the symptom burden variable was split into a dichotomy as a requirement for the logistic regression test. In addition, this study only analysed a single of HD session duration but if the dose of HD time duration was adjusted based on the golden standard to achieve adequate HD, which was 3 times a week, 4-5 hours duration (Sukandar, 2006), the HD session duration were still inadequate (majority, HD frequency was 2 times a week, HD session duration was 3-4 hours). An inadequate HD may cause metabolic waste and symptoms increase due to uremia. This was in line with the results of study by Danquah et al. (2010) who stated that CKD-HD patients with a longer interdialytic interval (two days) reported higher symptom burden score than patients with one-day interdialytic interval.

The positive correlation between postdialysis recovery time and symptom burden in this study was corresponded with several studies result (Caplin et al., 2011; Lopes et al., 2014; Rayner et al., 2014). The pathogenesis of a longer recovery time postdialysis was probably due to an osmotic imbalance during the hemodialysis process that caused neurological symptoms (Rayner et al., 2014). Thus, dialysis nurses need to prevent hemodialysis-related complications which contributed to longer recovery time that may risk a higher symptom burden.

There was not any association between gender, $\mathrm{Hb}$ level, nutritional status, physical activity, social support and symptom burden. In general, studies stated that female was associated with symptom burden (Almutary et al., 2016; Danquah et al., 2010; Caplin, Kumar, \& Davenport, 2011, Karasneh et al., 2020). The possibility of a balanced gender composition between women and men $(51.4 \%$ vs $50 \%)$ in the high symptom burden category in this study caused no association. Furthermore, the small difference in the range of $\mathrm{Hb}$ level data between symptom burden categories was probably the reason why there was no relationship between $\mathrm{Hb}$ levels and symptom burden. As far as we know, the result of this study was a novelty in analysing the absence of an association between nutritional status and symptom burden associated with CKD symptoms that had not been evaluated before. Previous studies had stated that there was a relationship between nutritional status and symptom burden related to gastrointestinal symptoms (Randall et al., 2019 and Silva et al., 2012). The type of symptom assessed was likely to be the reason why there was no association in this study. Furthermore, no association was found between physical activity and symptom burden, this was in line with the result of study by Sheshadri et al. (2019). The possible reason why there was no association between physical activity and symptom load was because $40 \%$ of respondents in this study still had very active physical activity. The absence of association between social support and symptom burden was consistent with the results of the study by Dano et al. (2018) and Gao et al. (2016). Good social support and the small differences in the range of social support data between categories of symptom burden were probably the reasons why there was no relation between social support and symptom burden.

There was a moderate strength association between the depression level and symptom burden. In the multivariate analysis, there were two variables that influenced high symptom burden, the HD session duration and depression level. However, depression level was the most dominant factor associated with 
symptom burden. This was corresponded with the results of other studies which stated that the higher the level of depression, the higher the symptom burden (Son et al., 2009; Song et al., 2018; Wan Zukiman et al. 2017). In this study, the five highest symptoms that were present simultaneous in all symptom dimensions were fatigue, sleep disturbance, dry skin, muscle pain, bone or joint pain, and decreased interest in sex. Most of these physical symptoms were somatic symptoms related to psychological symptoms (fatigue, pain, pruritus, sleep disturbances and sexual dysfunction) (Shirazian et al., 2017). The assessment of depression in CKD-HD patients are complex, because physical and psychological interacted with each other, depressive symptoms present were overlapping with uremic symptoms (Shirazian et al., 2017).

Dialysis process was one of the stressors caused psychological problems, where the patient felt depressed, lacked of social support from the closest person, tired with the dialysis process, felt hopeless, anxious, had thoughts of loss, high awareness of death, and felt uncertain about the disease (Avdal et al., 2020; Cervantes et al., 2016). In addition, lifestyle changes, feeling overwhelmed by self-care, physical symptoms arising from uremia and medication were also associated with depression (Kustimah et al., 2020; Shirazian et al., 2017). The dialysis process and uremic conditions may activate an inflammatory response that results in the release of proinflammatory cytokines (Sukandar, 2006). Several studies have shown that levels of interleukin-6 was found higher in CKD-HD patients with depression (Bossola et al., 2015; Wang et al., 2012). Depression in CKDHD may worsen CKD-related symptoms, affect the adherence to a treatment, increase the incidence of hospitalization, morbidity, malnutrition, and worsen the quality of life (Garcia-Llana et al., 2014; Treadwell, 2017).

This study implicated nursing practice in the hemodialysis unit as an effort to reduce symptom burden, which emphasizes the importance of giving attention to the patient psychological aspects. This psychological problem is often unrecognized because the somatic symptoms are similar to uremic symptoms and the low management (Chen,
Wang, \& Lang, 2016). The initial effort that can be made in depression management is screening ofdepression. Dialysisnurses should receive training in the administrating protocol of the depression screening questionnaire and how to triage patients who are positive for depression (Hedayati et al., 2012). The HD unit should establish policies regarding depression screening and algorithms for treating patients with depression. Regarding depression treatment, dialysis nurses need to involve doctors, psychologists or counsellors in a multidisciplinary team, and take courses on psychological interventions to improve depression level (Farrokhi, 2012). The non-pharmacological therapy proposed was cognitive behavioural therapy. Other alternative options proposed were exercise, anxiety treatment, conflict management, education for social life management, music therapy (Hedayati et al., 2012), and life reviews and cognitive therapy (Sutinah, 2020).

\section{Conclusion}

It is concluded that high symptom burden in CKD-HD patients was strongly influenced by the depression level, which means that CKDHD patients with depression are more at risk of experiencing a high symptom burden than those who are not depressed. Dialysis nurses need to give attention to psychological aspects and be able to distinguish between psychological and uremic symptoms. The high symptom burden can be reduced by improving depression levels in CKDHD patients, by screening depression, providing mentoring, nursing education and interventions, or developing depressionrelated interventions.

The limitation of this study was the small number of samples involved, so that the relative results of this study cannot be generalized to a wider population. This study does not have information about HD adequacy among respondents, that may be source of residual confounder. Future studies may need to examine other factors (comorbidity, hemodialysis frequency per week, quantification of HD and IL-6 adequacy). Longitudinal design studies are 
Early Octavia Limbong: Symptom Burdens Associated Factors among Hemodialysis Patients

warranted to explore the symptom burden and depression at each stage of CKD and types of modalities and interventions to reduce the symptom burden associated with depression in CKD-HD patients.

\section{References}

Abrori, I., \& Ahmad, R. A. (2018). Kualitas hidup penderita tuberkulosis resisten obat di kabupaten Banyumas. (Quality of life for drug resistant tuberculosis patients in Banyumas district). Berita Kedokteran Masyarakat, 34(2), 56-61.

Almutary, H., Bonner, A., \& Douglas, C. (2013). Review article symptom burden In chronic kidney disease: A review Of recent Literature. Journal of Renal Care, 1-11. https://doi.org/doi:10.1111/j.17556686.2013.12022.x

Almutary, H., Bonner, A., \& Douglas, C. (2015). Arabic translation, adaptation and modification of the dialysis symptom index for chronic kidney disease stages four and five. BMC Nephrology, 16(36), 1-8. https:// doi.org/10.1186/s12882-015-0036-2

Almutary, H., Bonner, A., \& Douglas, C. (2016). Which patients with chronic kidney disease have the greatest symptom burden? A comparative study of advanced CKD stage And Dialysis Modality. Journal of Renal Care, 42(2), 73-82. https://doi.org/10.1111/ jorc. 12152

Avdal, E.U., Ayvaz, İ., Özgursoy Uran, B., Yildirim, J., Sofulu, F., \& Pamuk, G. (2020). Opinions of hemodialysis and peritoneum patients regarding depression and psychological problems which they experience: A qualitative study. Journal of Infection and Public Health. https://doi. org/10.1016/j.jiph.2020.02.041

Bossola, M., Di Stasio, E., Giungi, S., Rosa, F., \& Tazza, L. (2015). Fatigue is associated with serum interleukin-6 levels and symptoms of depression in patients on chronic hemodialysis. Journal of Pain and Symptom Management, 49(3), 578-585. https://doi. org/10.1016/j.jpainsymman.2014.07.009

Brennan, F., Siva, B., \& Crail, S. (2013). Appropriate sssessment of symptom burden and provision of patient informatio. Nephrology, n/a-n/a. https://doi.org/10.1111/ nep. 12075

Brislin, R. W. (1970). Back-Translation for cross-cultural research. Journal of CrossCultural Psychology, 1(3), 185-216. https:// doi.org/10.1177/135910457000100301

Caplin, B., Kumar, S., \& Davenport, A. (2011). Patients' perspective of haemodialysisassociated symptoms. Nephrology Dialysis Transplantation, 26(8), 2656-2663. https:// doi.org/10.1093/ndt/gfq763

Cervantes, L., Hull, M., Keniston, A., Chonchol, M., Hasnain-Wynia, R., Fischer, S. (2018). Symptom Burden among Latino Patients with End-Stage Renal Disease and Access to Standard or Emergency-Only Hemodialysis. Journal of Palliative Medicine, $X X(\mathrm{XX}), \quad 1-5 . \quad$ https://doi.org/10.1089/ jpm.2017.0663

Chen, S. F., Wang, I. J., \& Lang, H. C. (2016). Risk of major depression in patients with chronic renal failure on different treatment modalities: A matched-cohort and population-based study in Taiwan. Hemodialysis International, 20(1), 98-105. https://doi.org/10.1111/hdi.12334

Clarke, A. L., Young, H. M. L., Hull, K. L., Hudson, N., Burton, J. O., \& Smith, A. C. (2015). Motivations and barriers to exercise in chronic kidney disease : a qualitative study. Nephrol Dial Transplant, 30(June), 18851892. https://doi.org/10.1093/ndt/gfv208

Dano, S., Zhang, J., Towes, D., Ahmed, T., Novak, M., \& Musci, I. (2018). Social Support is associated with Symptom Burden. Mukci Novak Kidney Health Education and Reearch Group.

Danquah, F. V. N., Zimmerman, L., Diamond, P. M., Meininger, J., \& Bergstrom, N. (2010). Frequency, Severity, and Distress OfDialysisRelated Symptoms Reported by Patients on Hemodialysis Continuing. Nephrology 
Early Octavia Limbong: Symptom Burdens Associated Factors among Hemodialysis Patients

Nursing Journal, 37(6), 627-640.

Davison, S. N. \& Jhangri, G. S. (2010). Impact of Pain and Symptom Burden on the HealthRelated Quality of Life of Hemodialysis Patients. Journal of Pain and Symptom Management, 39(3), 477-485. https://doi. org/10.1016/j.jpainsymman.2009.08.008

Delmas, P., Cohen, C., Loiselle, M.-C., Antonini, M., Pasquier, J., \& Burnier, M. (2017). Symptoms and quality of life from patients undergoing hemodialysis in Switzerland. Clinical Nursing Studies, 6(2), 63. https://doi.org/10.5430/cns.v6n2p63

Desbiens, N. A., Mueller-rizner, N., Connors, A. F., Wenger, N. S., Lynn, J., \& Investigators, S. (1999). The Symptom Burden of Seriously Ill Hospitalized Patients. Journal of Pain and Symptom Management, 17(4), 248-255. https://doi.org/10.1016/ s0885-3924(98)00149-3

Gao, Y., Zhou, Y., Guo, C. X., \& Zhao, J. F. (2016). The relationship among hope, symptom distress, social support, coping style and monthly income in maintenance hemodialysis patients: A structural equation model. International Journal of Clinical and Experimental Medicine, 9(10), 19717-19724.

Gapstur, R. L. (2007). Symptom Burden : A Concept Analysis and Implications for Oncology Nurses. Oncology Nursing Forum, 34(3), 673-681. https://doi.org/10.1188/07. ONF.673-680

Farrokhi, F. (2012). Depression Among Dialysis Patients. Iranian Journal of Kidney Diseases, 6(6), 403-406.

García-Llana, H., Remor, E., del Peso, G., \& Selgas, R. (2014). The role of depression, anxiety, stress and adherence to treatment in dialysis patients' health-related quality of life: a systematic review of the literature. Nefrologia, 34(5), 637-657. https://doi. org/10.3265/Nefrologia.pre2014.Jun.11959

Hedayati, S. S., Yalamanchili, V., \& Finkelstein, F. O. (2012). A practical approach to the treatment of depression in patients with chronic kidney disease and end-stage renal disease. Kidney International, 81(3), 247255. https://doi.org/10.1038/jid.2014.371

Indonesian Renal Registry/IRR (2018). 11th Report of Indonesian Renal Registry. Retrieved March 14, 2020, from https://www. indonesianrenalregistry.org/data/IRR \%20 2018.pdf

Kalantar-Zadeh, K., Kleiner, M., Dunne, E., Lee, G. H., \& Luft, F. C. (1999). A modified quantitative subjective global assessment of nutrition for dialysis patients. Nephrology Dialysis Transplantation, 14(7), 1732-1738. https://doi.org/10.1093/ndt/14.7.1732

Karasneh, R., Al, S., Shoroq, A., Osama, M. A., \& Sahar, Y. A. (2020). Predictors of symptom burden among hemodialysis patients : a cross sectional study at 13 hospitals. International Urology and Nephrology. https://doi.org/10.1007/s11255020-02458-2

Kementrian Kesehatan RI. (2016). Pedoman Kegiatan Keafiatandi TempatKerja "Wellness Program at Workplace”. Retrieved March 14, 2020, from https://dokumen.tech/document/ pedoman-kegiatan-keafiatan-di-tempatkerja-staffuiac-nutritional-management.html.

Kopple, J. ., Kim, J. ., Shapiro, B. ., Zhang, M., Li, Y., Porszasz, J., ... Kalantar-Zadeh, K. (2015). Factors affecting daily physical activity and physical performance in maintenance dialysis patients. J Ren Nutr., 25(2), 217-222. https://doi.org/10.1053/j. jrn.2014.10.017

Kroenke, K., Spitzer, R. L., Williams, J. B. (2001). The PHQ-9: validity of a brief depression severity measure. Journal of General Internal Medicine, 16(9): 606613. $\quad$ https://doi.org/10.1046/j.15251497.2001.016009606.x

Kustimah, K., Prathama Siswadi, A. G., Djunaidi, A., \& Iskandarsyah, A. (2020). Quality of Life among Patients Undergoing Haemodialysis in Bandung: A mixed methods study. Jurnal Keperawatan Padjadjaran, 8(1). https://doi.org/10.24198/jkp.v8il.1330. 
Lenz, E. R., Pugh, L. C., Milligan, R. A., Gift, A., \& Suppe, F. (1997). Theory unpleasant symptoms. $A d v$ Nurs Sci. https://doi. org/10.1097/00012272-199703000-00003

Li, H., Xie, L., Yang, J., \& Pang, X. (2018). Symptom burden amongst patients suffering from end-stage renal disease and receiving dialysis: A literature review. International Journal of Nursing Sciences, 5(4), 427-431. https://doi.org/10.1016/j.ijnss.2018.09.010

Linden, A. Van Der. (2019). Cross-cultural validation of the Patient Health Questionnaire (PHQ-9) in Bahasa Indonesia to measure depression among people affected by leprosy in Central Java [Master's thesis, Vrije Universteit]. Vrije Universiteit, Amsterdam.

Lindsay, R. M., Heidenheim, P. A., Nesrallah, G., \& Garg, A. X. (2006). Minutes to recovery after a hemodialysis session : A simple healthrelated quality of life question that Is reliable , Valid, and Sensitive to Change, 952-959. https://doi.org/10.2215/CJN.00040106

Lopes, G. B., Silva, L. F., Pinto, G. B., Catto, L. F., Martins, M. T., Dutra, M. M., \& Lopes, A. A. (2014). Patient's response to a simple question on recovery after hemodialysis session strongly associated with scores of comprehensive tools for quality of life and depression symptoms. Quality of life research : an international journal of quality of life aspects of treatment, care and rehabilitation, 23(8), 2247-2256. https://doi.org/10.1007/ s11136-014-0666-Z

Lowney, A. C., Myles, H. T., Bristowe, K., Lowney, E. L., Shepherd, K., Murphy, M., ... Murtagh, F. E. M. (2015). Understanding what influences the health-related quality of life of hemodialysis patients : A collaborative study in England and Ireland. Journal of Pain and Symptom Management, 50(6), 778-785. https://doi.org/10.1016/j. jpainsymman.2015.07.010

Ng, M. S. N., So, W. K. W., Wong, C. L., Hui, Y. H., Ho, E. H. S., Choi, K. C., ... Miaskowski, C. (2020). Stability and impact of symptom Clusters in Patients with endstage renal disease undergoing dialysis.
Journal of Pain and Symptom Management, 59(1), 67-76. https://doi.org/10.1016/j. jpainsymman.2019.08.013

Nur, E. I. Y. (2017). Validitas Dialysis Malnutrition Score (DMS) dan Nutritional Risk Index (NRI) Dibandingkan Dengan Subjective Global Assessment (SGA) Pada Pasien Gagal Ginjal yang Menjalani Hemodialisis. [Master's thesis, Universitas Sebelas Maret]. Universitas Sebelas Maret, Surakarta, Indonesia.

Orenstein, G.A., \& Lewis, L. (2020). Eriksons Stages of Psychosocial Development. In StatPearls. StatPearls Publishing.

PERNEFRI (Perhimpunan Nefrologi Indonesia) (2018). Konsensus Anemia pada Penyakit Ginjal Kronik Edisi II. (Consensus Anemia in Chronic Kidney Disease II Edition). PERNEFRI.

Polit, D.F. \& Beck, C.T. (2004). Nursing Research Principles and Methods. 7th ed. Philadelphia: Lippincots Williams \& Wilkins. Randall, A. M., Stevenson, J., Heaney, S., Notaras, S., Hoffman, A., Choi, P., ... Sud, K. (2019). Sun-102 Nutrition-Impact Symptom Burden in Patients Attending Renal Supportive Care. Kidney International Reports, 4(7), S199. https://doi.org/10.1016/j. ekir.2019.05.499

Rayner, H. C., Zepel, L., Fuller, D. S., Morgenstern, H., Karaboyas, A., Culleton, B. F., ... Robinson, B. M. (2014). Recovery Time, Quality of Life, and Mortality in Hemodialysis Patients: The Dialysis Outcomes and Practice Patterns Study\&nbsp;(DOPPS). American Journal of Kidney Diseases, 1-9.https://doi. org/10.1053/j.ajkd.2014.01.014

Sexton, D. J., Lowney, A. C., Seaghdha, C. M. O., Murphy, M., Brien, T. O., Casserly, L. F., ... Conlon, P. J. (2016). Do patientreported measures of symptoms and health status predict mortality in hemodialysis? An assessment of POS-S Renal and EQ-5D. Hemodialysis International 2016; 1-13. https://doi.org/10.1111/hdi.12415

Sherbourne, C. D., \& Stewart, A. L. (1991). 
Early Octavia Limbong: Symptom Burdens Associated Factors among Hemodialysis Patients

The MOS social support survey. Social Science and Medicine, 32(6), 705-714.https:// doi.org/10.1016/0277-9536(91)90150-B

Sheshadri, A., Kittiskulnam, P., \& Johansen, K. L. (2019). Higher physical activity is associated with less fatigue and insomnia among patients on hemodialysis. Kidney International Reports, 4(2), 285-292. https:// doi.org/10.1016/j.ekir.2018.10.014

Shirazian, S., Grant, C. D., Aina, O., Mattana, J., \& Khorassani, F. (2017). Depression in Chronic Kidney Disease and End-Stage Renal Disease: Similarities and Differences in Diagnosis, Epidemiology, and Management. Kidney International Reports, 2(1), 94-107. https://doi.org/10.1016/j.ekir.2016.09.005

Silva, L. F., Lopes, G. B., Matos, C. M., Brito, K. Q., Amoedo, M. K., Azevedo, M. F., ... Lopes, A. A. (2012). Gastrointestinal Symptoms and Nutritional Status in Women and Men on Maintenance Hemodialysis. Journal of Renal Nutrition, 22(3), 327-335. https://doi.org/10.1053/j.jrn.2011.07.007

Son, Y.-J., Choi, K.-S., Park, Y.-R., Bae, J.-S., \& Lee, J.-B. (2009). Depression, Symptoms and the Quality of Life in Patients on Hemodialysis for End-Stage Renal Disease. American Journal of Nephrology, 29(1), 3642. https://doi.org/10.1159/000150599

Song, M. K., Paul, S., Ward, S. E., Gilet, C. A., \& Hladik, G. A. (2018). One-Year Linear Trajectories of Symptoms, Physical Functioning, Cognitive Functioning, Emotional Well-being, and Spiritual Wellbeing Among Patients Receiving Dialysis. American Journal of Kidney Diseases, 72(2), 198-204. https://doi.org/10.1053/j. ajkd.2017.11.016

Sugiyono. (2018). Metode Penelitian Kuantitatif. (Quantitative Research Methods). Alfabeta.

Sukandar, E. (2006). Gagal Ginjal dan Panduan Terapi Dialisis Tahun 2006. (Renal Failure and Dialysis Therapy Guide,
2006.) Pusat Informasi Ilmiah (PPI) Bagian Ilmu Penyakit Dalam Fakultas Kedokteran UNPAD/RS. Dr. Hasan Sadikin.

Sutinah (2020). Effect of Life Review and Cognitive Therapy on Depression in Patients with Chronic Renal Failure. Jurnal Keperawatan Padjadjaran, 8(2), 1-8. https:// doi.org/10.24198/jkp.v8i2.1342

Topolski, T. D., LoGerfo, J., Patrick, D. L., Williams, B., Walwick, J., \& Patrick, M. B. (2006). The Rapid Assessment of Physical Activity (RAPA) among older adults. Preventing Chronic Disease, 3(4), 1-8.

Treadwell, A. A. (2017). Examining Depression in Patients on Dialysis. American Nephrology Nurses Association., 44(4), 295307.

USRDS (2018). United States Renal Data System Annual Report: Executive Summary. Retrieved March 14, 2020, from https:// www.usrds.org/2018/download/v1 00 ExecSummary 18.pdf.

Wan Zukiman, W. Z. H., Yaakup, H., Zakaria, N. F., \& Shah, S. A. Bin. (2017). Symptom Prevalence and the Negative Emotional States in End-Stage Renal Disease Patients with or without Renal Replacement Therapy: A Cross-Sectional Analysis. Journal of Palliative Medicine, 20(10), 1127-1134. https://doi.org/10.1089/jpm.2016.0450

Wang, L. J., Wu, M. S., Hsu, H. J., Wu, I. W., Sun, C. Y., Chou, C. C., ... Chen, C. K. (2012). The relationship between psychological factors, inflammation, and nutrition in patients with chronic renal failure undergoing hemodialysis. International Journal of Psychiatry in Medicine, 44(2), 105-118. https://doi.org/10.2190/PM.44.2.b

Yu, I., Huang, J., \& Tsai, Y. (2012). Symptom cluster among hemodialysis patients in Taiwan. Applied Nursing Research, 25(3),190-196. https://doi.org/10.1016/j. apnr.2010.11.002. 